\title{
ALKANOL AND STEROL DEGRADATION IN A SEDIMENT CORE FROM THE CONTINENTAL SLOPE OFF SOUTHWESTERN TAIWAN
}

\author{
Woei-Lih Jeng ${ }^{1 *}$, Chih-An Huh ${ }^{2}$, and Chin-Liang Chen ${ }^{1}$ \\ 1. Institute of Oceanography, National Taiwan University, Taipei, Taiwan, Republic of China \\ 2. Institute of Earth Sciences, Academia Sinica, Taipei, Taiwan, Republic of China
}

(Received in Germany 13 May 1997; accepted 4 June 1997)

\begin{abstract}
A sediment core (ca. $36 \mathrm{~cm}$ in length and sectioned at $4 \mathrm{~cm}$ intervals) collected from the anoxic continental slope off southwestern Taiwan has been analyzed for alkanols and sterols in the extractable and bound forms to understand their degradation in this reducing environment during diagenesis. Generally speaking, the two compound classes (both extractable and bound) degrade faster in the upper core and slower in the lower core; however, extractable phytol degrades sharply from sections 1 to 2 and gradually from section 2 down. The calculated apparent rate constants $\left(y^{-1}\right)$ for the extractable phytol, $\Sigma$ n-alkanols, and $\Sigma$ sterols are respectively $0.015,0.011$, and 0.010 ; and those for the bound phytol, $\Sigma$ n-alkanols, and $\Sigma$ sterols are respectively $0.011,0.007$ and 0.007 . The bound form is slightly less reactive than the extractable form. These constants are at least one order of magnitude lower than those reported for two shallow coastal marine sediments--Cape Lookout Bight and Peru, but are similar to or slightly lower than those reported for the anoxic Black Sea deep basin. The interesting result can be attributed to anoxicity which plays the most important role during lipid degradation in the sediment. $\odot 1997$ Elsevier Science Ltd
\end{abstract}

\section{INTRODUCTION}

Burial of organic matter on the seafloor is one of the important benthic processes and plays a major role in the global carbon budget. The buried organic matter is subject to different rates of degradation. The rate and extent of degradation of sedimentary organic compounds depend strongly on molecular structure of the substrate, protective effects offered by association of organic matter with particle matrices, and sedimentary redox conditions that affect the activity of benthic organisms [1]. 
Degradation rates of lipids during early diagenesis vary with different compound classes. Terrigenous n-alkane concentrations remain constant throughout the sediment cores $(42,62$, and $72 \mathrm{~cm})$ from Buzzards Bay (Massachusetts), the Gulf of Maine, and Hudson Canyon in some cases [2], but are attenuated with depth in the sediment cores from the Porcupine Abyssal Plain in the north-eastern Atlantic Ocean in other cases [3]. In Lake Michigan hydrocarbons have been shown to degrade two to three times slower than does total organic matter [4]. Fatty acids as a group are about 10 times more susceptible to degradation than are hydrocarbons [4,5]. Using a diagenetic model consisting of labile and refractory organic pools to calculate first-order degradation rate constants, Sun and Wakeham [6] provide a more extensive order of relative reactivity for several lipid classes in Black Sea sediment, in which sterols and nalkanols have similar reactivity.

Lipid degradation has been studied for anoxic Black Sea sediments [6] and for oxygenated shallow coastal sediments of Cape Lookout Bight [7]. The area off southwestern Taiwan is rather unique since the water column is generally oxic and the sediments are mostly anoxic. The objective of this study was to understand lipid degradation in this environment by analyzing alkanols and sterols in the extractable and bound forms.

\section{EXPERIMENTAL}

A box core sample was taken from an anoxic area on the upper continental slope off southwestern Taiwan $\left(22^{\circ} 32.45^{\prime} \mathrm{N}, 120^{\circ} 05.02^{\prime} \mathrm{E}\right)$ in a water depth of $354 \mathrm{~m}$ on board the $\mathrm{R} / \mathrm{V}$ Ocean Researcher \#1 for this study. A sub-core (ca. $36 \mathrm{~cm}$ in length) was extruded from the core liner and sectioned at $4 \mathrm{~cm}$ intervals from the top. Each sediment section was freeze-dried and ground. 1-Nonadecanol was added to the sediment and extracted with benzene/methanol (1:1) in a Soxhlet apparatus for $24 \mathrm{~h}$. The spiked extract was concentrated and hydrolyzed with methanolic $\mathrm{KOH}$. The neutral lipids were extracted with n-hexane. The nonsaponifiable lipids were subjected to silica gel (deactivated with $5 \% \mathrm{H}_{2} \mathrm{O}$ ) column chromatography. Less polar lipids were ehted with $n$-hexane/chloroform $(2: 3, \mathrm{v} / \mathrm{v})$, and the fraction containing fatty alcohols and sterols was isolated by using a mixture of chloroform/methanol $(4 / 1, \mathrm{v} / \mathrm{v})$. For releasing bound lipids, after adding the internal standard, the extracted sediment residue was subjected to alkaline hydrolysis (overnight) for releasing bound lipids, followed by filtration, $n$-hexane extraction and alcohol/sterol isolation. The isolated alcohols and sterols were taken to dryness, redissolved in benzene, and derivatized with NO-Bis(trimethylsilyl) acetamide. Alcohols and sterols (as TMS ethers) were analyzed by capillary gas chromatography using an HP $5890 \mathrm{~A}$ gas chromatograph equipped with a split/splitless injector and an FID. An SGE (Australia) OCI-5 cool on-column injector was also fitted in the gas chromatograph for quantitation. Separation was achieved by an SE-30 capillary cohumn (30 $\mathrm{m} \mathrm{x}$ $0.25 \mathrm{~mm}$ i.d.). Oven temperature programming was: $45-90^{\circ} \mathrm{C}$ at $15^{\circ} / \mathrm{min}, 90-270^{\circ} \mathrm{C}$ at $3^{\circ} \mathrm{C} / \mathrm{min}, 270^{\circ} \mathrm{C}$ for $20 \mathrm{~min}, 270-280^{\circ} \mathrm{C}$ at $10^{\circ} \mathrm{C} / \mathrm{min}$, and $280^{\circ} \mathrm{C}$ for $20 \mathrm{~min}$. Detector was at $300^{\circ} \mathrm{C}$, and hydrogen was used as the carrier gas. Identification was accomplished by coinjection with authentic standards; positive confirmation was obtained using an HP 5890 gas chromatograph coupled to an HP 5970B mass selective detector. Quantitation was achieved by capillary GC using an electronic integrator (Chromapac C-R6A, Shimadzu, Japan). The analytical precision of lipids was calculated to be $2-8 \%$.

Sediment samples were oven-dried in air for $48 \mathrm{~h}$. Total organic carbon was determined by the 
dichormate-acid oxidation method [8] modified by addition of $\mathrm{Ag}_{2} \mathrm{SO}_{4}$ to $\mathrm{H}_{2} \mathrm{SO}_{4}$ at the rate of $15 \mathrm{~g} /$. Titration was carried out with an automatic titrator (Metrohm 702 SM Titrino, Switzerland). The relative standard deviation of TOC determination was generally $<1 \%$.

\section{RESULTS AND DISCUSSION}

In this study, we examine n-alkanols ranging from $\mathrm{C}_{14} \mathrm{OH}-\mathrm{C}_{28} \mathrm{OH}$ in which $\mathrm{C}_{19} \mathrm{OH}$ is the internal standard and $\mathrm{C}_{27} \mathrm{OH}$ is not reported here due to its coeluation with one unknown compound. The major sterols identified and quantified are as follows: (1) cholesta-5,22E-dien-3 $\beta$-ol, (2) $5 \alpha$-cholest-22E-en- $3 \beta$-ol, (3) cholest-5-en-3 $\beta$-ol, (4) $5 \alpha$-cholestan-3 $\beta$-ol, (5) 24 -methylcholesta-5,22E-dien-3 $\beta$-ol, (6) 24-methyl$5 \alpha$-cholest-22E-en-3 $\beta$-ol, (7) 24-methylcholesta-5,24(28)-dien-3 $\beta$-ol, (8) 24 -methylcholest-5-en-3 $\beta$-ol, (9) 24-methyl-5 $\alpha$-cholestan-3 $\beta$-ol, (10) 23,24-dimethylcholesta-5,22E-dien-3 $\beta$-ol, (11) 24-ethylcholesta5,22E-dien-3 $\beta$-ol, (12) 24-ethyl-5 $\alpha$-cholest-22E-en-3 $\beta$-ol, (13) 24 -ethylcholest-5-en- $3 \beta$-ol, and (14) 24 ethyl- $5 \alpha$-cholestan- $3 \beta$-ol. Gas chromatograms of alkanols and sterols are the same as those given elsewhere [9]. Representative examples of the concentrations of extractable and bound alkanols and sterols in the top two sections of the core $(0-4 \mathrm{~cm}$ and $4-8 \mathrm{~cm})$ are listed in Table 1 . The major features are that even-carbon-numbered n-alkanols outweigh odd-carbon-numbered ones and that cholest-5-en- $3 \beta$-ol is the most abundant sterol among all sterols. Predominant $n$-alkanols are $\mathrm{C}_{22} \mathrm{OH}, \mathrm{C}_{24} \mathrm{OH}, \mathrm{C}_{26} \mathrm{OH}$ and $\mathrm{C}_{28} \mathrm{OH}$, and the major sterols are 24 -methylcholest-5-en-3 $\beta$-ol, 24 -ethylcholesta-5,22E-dien-3 $\beta$-ol and 24 ethylcholest-5-en-3 $\beta$-ol, indicating a strong terrigenous input since the core is located close to land. This is in accord with those reported in the literature [10-12].

We have separated phytol from n-alkanols for discussion based on the fact that phytol is a branched acyclic isoprenoid alcohol with a double bond in its molecule. The downcore variations of extractable $\Sigma$ n-alkanols, phytol and $\Sigma$ sterols are given in Table 2, and they share a common characteristic feature: upper core (top 3 sections) shows a rapid concentration decline with increasing depth, and lower core gives lipid concentration profiles having a relatively slow decrease or fluctuating with increasing depth. This is in accord with the trend of total organic carbon content (Table 2). It is noted that compared to n-alkanols, phytol degrades dramatically at the core top from sections 1 to 2 ; from there down it degrades slowly as nalkanols (Table 2). This interesting result can be attributed to the molecular structure of phytol with a double bond; this phenomenon is similar to that of fatty acids in sedments--unsaturated fatty acids degrade faster than saturated fatty acids $[5,6]$. It is thought that only in areas with shallow water depth and higher sedimentation rate can the fast degradation rate of phytol be observed.

The concentrations of bound $\Sigma$ n-alkanols, phytol and $\Sigma$ sterols are given in Table 3, which shows that both bound alkanol and sterol concentrations decrease with increasing depth. Similarly, bound sterols (including $5 \beta$-cholestan-3 $\beta$-ol, $5 \beta$-cholestan- $3 \alpha$-ol, $5 \alpha$-cholestan- $3 \beta$-ol, and cholest- 5 -en- $3 \beta$-ol) decreasing with depth have also been observed in a sediment core from the anoxic Tan-Shui estuary, Taiwan [13]. However, Lee et al. [14] studying sterol diagenesis in recent sediments from Buzzards Bay found that extractable sterols decreased in concentration while bound sterols increased in concentration with depth. Recently, Sun et al. [15] in an incubation experiment using radiolabeled fatty acids found that cholest-5-en$3 \beta$-ol concentrations increased under oxic conditions but decreased under anoxic conditions and 
Table 1. Concentrations (ng/g) of extractable and bound alkanols and sterols in the top two sections of the sediment core.

\begin{tabular}{|c|c|c|c|c|}
\hline Compound & $\begin{array}{c}\text { Section } 1 \\
\text { Extractable } \\
\end{array}$ & $\begin{array}{c}\text { Section } 1 \\
\text { Bound } \\
\end{array}$ & $\begin{array}{c}\text { Section } 2 \\
\text { Extractable } \\
\end{array}$ & $\begin{array}{c}\text { Section } 2 \\
\text { Bound } \\
\end{array}$ \\
\hline \multicolumn{5}{|l|}{ Alkanols } \\
\hline $\mathrm{n}-\mathrm{C}_{14} \mathrm{OH}$ & 59 & 10 & 25 & 13 \\
\hline $\mathrm{n}-\mathrm{C}_{15} \mathrm{OH}$ & 32 & 7 & 15 & 7 \\
\hline $\mathrm{n}-\mathrm{C}_{16} \mathrm{OH}$ & 136 & 79 & 64 & 58 \\
\hline $\mathrm{n}-\mathrm{C}_{17} \mathrm{OH}$ & 27 & 8 & 11 & 7 \\
\hline $\mathrm{n}-\mathrm{C}_{18} \mathrm{OH}$ & 118 & 100 & 66 & 69 \\
\hline Phytol & 1049 & 788 & 375 & 521 \\
\hline $\mathrm{n}-\mathrm{C}_{20} \mathrm{OH}$ & 84 & 74 & 73 & 53 \\
\hline $\mathrm{n}-\mathrm{C}_{21} \mathrm{OH}$ & 19 & 13 & 25 & 12 \\
\hline $\mathrm{n}-\mathrm{C}_{22} \mathrm{OH}$ & 296 & 175 & 438 & 152 \\
\hline $\mathrm{n}-\mathrm{C}_{23} \mathrm{OH}$ & 45 & 18 & 29 & 13 \\
\hline $\mathrm{n}-\mathrm{C}_{24} \mathrm{OH}$ & 254 & 104 & 148 & 78 \\
\hline $\mathrm{n}-\mathrm{C}_{25} \mathrm{OH}$ & 52 & 10 & 62 & 8 \\
\hline $\mathrm{n}-\mathrm{C}_{26} \mathrm{OH}$ & 246 & 80 & 133 & 54 \\
\hline $\mathrm{n}-\mathrm{C}_{28} \mathrm{OH}$ & 471 & 74 & 210 & 35 \\
\hline \multicolumn{5}{|l|}{ Sterol no.* } \\
\hline 1 & 199 & 100 & 148 & 106 \\
\hline 2 & 97 & 35 & 93 & 34 \\
\hline 3 & 801 & 295 & 332 & 199 \\
\hline 4 & 544 & 81 & 166 & 61 \\
\hline 5 & 369 & 136 & 278 & 145 \\
\hline 6 & 255 & 45 & 148 & 45 \\
\hline 7 & 163 & 70 & 101 & 67 \\
\hline 8 & 424 & 116 & 161 & 85 \\
\hline 9 & 184 & 33 & 63 & 21 \\
\hline 10 & 113 & 28 & 80 & 26 \\
\hline 11 & 320 & 75 & 208 & 69 \\
\hline 12 & 232 & 44 & 158 & 45 \\
\hline 13 & 767 & 267 & 412 & 205 \\
\hline 14 & 599 & 130 & 290 & 104 \\
\hline
\end{tabular}

* identifications refer to text. 
Table 2. Concentrations of extractable $\Sigma$ n-alkanols, phytol, and $\Sigma$ sterols along with total organic carbon (TOC) content.

\begin{tabular}{ccccc}
\hline Core section & $\sum$ n-alkanols(ng/g) & phytol (ng/g) & $\sum$ sterols (ng/g) & TOC (g/100g) \\
\hline 1 & 1839 & 1049 & 5067 & 0.62 \\
2 & 1299 & 375 & 2638 & 0.60 \\
3 & 792 & 318 & 1834 & 0.54 \\
4 & 867 & 227 & 1511 & 0.50 \\
5 & 743 & 207 & 1621 & 0.51 \\
6 & 690 & 188 & 1248 & 0.48 \\
7 & 707 & 185 & 1365 & 0.49 \\
8 & 679 & 190 & 1444 & 0.50 \\
9 & 570 & 170 & 1309 & 0.49 \\
\hline
\end{tabular}

that more fatty acids appeared in the bound fraction under oxic than anoxic conditions. It appears that redox conditions play a crucial role in lipid diagenesis.

In addition, percent bound concentration is calculated by

$\%=$ [bound concentration/(extractable + bound concentrations) $] \times 100$

The results are included in Table 3. It is seen that for $n$-alkanols and sterols about $1 / 3$ of the compounds are left behind after solvent extraction and for phytol over $1 / 2$ of the compound remains nonextractable. It is interesting to note that from sections 1 to 2 bound phytol increases sharply from 43 to $58 \%$ while extractable phytol decreases abruptly from 1049 to $375 \mathrm{ng} / \mathrm{g}$ (Table 2). This might suggest that part of extractable phytol is transformed into the bound form.

To calculate apparent degradation rate constants for $\mathbf{n}$-alkanols, phytol and sterols, we assume lipids are degraded by first-order kinetics and at steady state, and the following equation is used [7].

$\ln \mathrm{C}=\ln \mathrm{C}_{0}-\mathrm{k}(\mathrm{z} / \mathrm{s})$

where $\mathbf{C}=$ lipid concentration at depth

$\mathrm{C}_{0}=$ lipid concentration at $\mathrm{z}=\mathbf{0}$

$k=$ apparent rate constant $\left(y^{-1}\right)$

$\mathrm{z}=$ core depth $(\mathrm{cm})$

$\mathrm{s}=$ sedimentation rate $(\mathrm{cm} / \mathrm{y})$

The apparent rate constant can be estimated from the linear regression of $\log _{e}$ lipid concentrations versus $\mathrm{z} / \mathrm{s}$. The mean depth of each core section is used for $\mathrm{z}$; sedimentation rate is $0.33 \mathrm{~cm} / \mathrm{y}$ determined by ${ }^{210} \mathrm{~Pb}$ chronology [16]. The results are given in Table 4. It shows that for the extractable form, the apparent rate constants $\left(y^{-1}\right)$ in decreasing order are phytol $(0.015)>\Sigma$ sterols $(0.011)>\Sigma$ n-alkanols $(0.010)$ and that for the bound form, the apparent rate constants $\left(\mathrm{y}^{-1}\right)$ in decreasing order are phytol $(0.011)>$ $\Sigma$ sterols $(0.007)=\Sigma \mathrm{n}$-alkanols $(0.007)$. For alkanols, the apparent rate constants of phytol (unsaturated) are slightly higher than those of $\Sigma$ n-alkanols (saturated). This result is similar to that of fatty acids-unsaturated fatty acids are relatively more reactive than saturated fatty acids [15]. Further, bound lipids 
Table 3. Concentrations of bound $\Sigma \mathbf{n}$-alkanols, phytol, and $\Sigma$ sterols. Figures in parentheses are the \% bound form ( $\%$ of extractable and bound forms).

\begin{tabular}{cccc}
\hline Core section & $\Sigma$ n-alkanols (ng/g) & phytol (ng/g) & $\sum$ sterols (ng/g) \\
\hline 1 & $752(29 \%)$ & $788(43 \%)$ & $1455(22 \%)$ \\
2 & $559(30 \%)$ & $521(58 \%)$ & $1212(32 \%)$ \\
3 & $428(35 \%)$ & $421(57 \%)$ & $1020(36 \%)$ \\
4 & $413(32 \%)$ & $285(56 \%)$ & $855(36 \%)$ \\
5 & $452(38 \%)$ & $309(60 \%)$ & $886(35 \%)$ \\
6 & $359(34 \%)$ & $244(56 \%)$ & $694(36 \%)$ \\
7 & $408(37 \%)$ & $240(56 \%)$ & $809(37 \%)$ \\
8 & $397(37 \%)$ & $299(61 \%)$ & $804(36 \%)$ \\
9 & $320(36 \%)$ & $238(58 \%)$ & $703(35 \%)$ \\
average & $34 \%$ & $56 \%$ & $34 \%$ \\
\hline
\end{tabular}

Table 4. Linear regressions between $\log _{e}$ compound concentrations (ng/g) and core depth ( $\mathrm{z}$, $\mathrm{cm}) /$ sedimentation rate $(\mathrm{s}, \mathrm{cm} / \mathrm{y}) . \quad \mathrm{r}=$ correlation coefficient, $\mathrm{p}=$ significance value.

\begin{tabular}{|c|c|c|}
\hline Regression & $\mathbf{r}$ & p \\
\hline \multicolumn{3}{|l|}{ Extractable: } \\
\hline $\ln \left(\sum\right.$ n-alkanols $)=7.28-0.010(\mathrm{z} / \mathrm{s})$ & -0.88 & 0.002 \\
\hline $\ln ($ phytol $)=6.38-0.015(\mathrm{z} / \mathrm{s})$ & -0.83 & 0.005 \\
\hline $\ln \left(\sum\right.$ sterols $)=8.09-0.011(\mathrm{z} / \mathrm{s})$ & -0.81 & 0.008 \\
\hline \multicolumn{3}{|l|}{ Bound: } \\
\hline $\ln (\Sigma$ n-alkanols $)=6.44-0.007(\mathrm{z} / \mathrm{s})$ & -0.85 & 0.004 \\
\hline $\ln ($ phytol $)=6.41-0.011(\mathrm{z} / \mathrm{s})$ & -0.86 & 0.003 \\
\hline $\ln \left(\sum\right.$ sterols $)=7.17-0.007(\mathrm{z} / \mathrm{s})$ & -0.89 & 0.002 \\
\hline
\end{tabular}

are relatively less reactive than extractable lipids. This result also is similar to that of fatty acids. Van Vleet and Quinn [17] studied solvent-extractable fatty acids and fatty acids-released by hydrolysis from sediment cores and found that the extractable, free acids are more labile than the nonextractable, bound forms. One possible explanation is that the compounds in the bound form are probably closely associated with sediment matrices and are apparently relatively unavailable for microorganisms. A comparison of the present rate constants with those of other areas is given in Table 5. Our values are in agreement with those of the Black Sea, but one-order-of-magnitude lower than those of two coastal marine sediments-Cape Lookout Bight and Peru. Interestingly, the present core is from the coastal marine environment; however, its rate constants are similar to those of the anoxic Black Sea basin. The marine environment of the Black Sea is totally different from that of Taiwan continental slope (Table 6). Our sample site is 
Table 5. Comparison of first-order degradation rate constants $\left(y^{-1}\right)$ for lipids in different depositional environments.

\begin{tabular}{lcccc}
\hline Lipid component & Black Sea* & $\begin{array}{c}\text { Cape Lookout } \\
\text { Bight* }\end{array}$ & Peru* & $\begin{array}{c}\text { Taiwan continental slope } \\
\text { (this study) }\end{array}$ \\
\hline Total alkanols & 0.024 & $0.07^{* *}$ & $0.06,0.17^{* *}$ & 0.010 \\
Total sterols & 0.017 & 0.26 & 0.32 & 0.011 \\
\hline
\end{tabular}

*from Sun and Wakeham [6]

** single compound

Table 6. Comparison between the Black Sea and Taiwan continental slope.

\begin{tabular}{lccccc}
\hline Area & Water depth & $\begin{array}{c}\text { Sedimentation } \\
\text { rate }\end{array}$ & $\begin{array}{c}\text { Redox in } \\
\text { water column }\end{array}$ & $\begin{array}{c}\text { Redox in } \\
\text { sediment }\end{array}$ & $\begin{array}{c}\text { TOC } \\
(\mathrm{g} / 100 \mathrm{~g})\end{array}$ \\
\hline Black Sea* & $2094 \mathrm{~m}$ & $<0.02 \mathrm{~cm} / \mathrm{y}$ & $\begin{array}{c}\text { anoxic } \\
(>100 \mathrm{~m})\end{array}$ & anoxic & $8.3-3.3$ \\
$\begin{array}{l}\text { Taiwan conti- } \\
\text { nental slope }\end{array}$ & $354 \mathrm{~m}$ & $0.33 \mathrm{~cm} / \mathrm{y}$ & $\begin{array}{c}\text { oxic } \\
\text { mostly } \\
\text { anoxic }\end{array}$ & $0.62-0.48$ \\
\hline
\end{tabular}

* from Sun and Wakeham [6]

located at a water depth of $354 \mathrm{~m}$ on the upper continental slope and has a high sedimentation rate of 0.33 $\mathrm{cm} / \mathrm{y}$. The deposited organic matter is relatively more labile and less altered; therefore, the rate constants are expected to be higher. The reason for this discrepancy is that anoxicity in sediment must play a crucial role and is responsible for the present result. The sample site borders two known reducing environments: one, to the east, there exist a series of mud diapirs [18] which evolve methane resulting in high methane concentrations in bottom water (range 100-352 $\mathrm{nl} /$, Jeng, unpubl. data); the other, to the south, deposits are characterized by pyrite vein facies [19]. Another factor might be taken into consideration. The area off southwestern Taiwan, neighboring Kao-hsiung Harbor, is subject to repeated oil spills and chronic inputs of oil due to heavy tanker traffic and operations, other ship traffic, and industrial activities; this area has been heavily polluted by petroleum hydrocarbons [20]. As an example, the carbon preference indices of n-alkanes (in the range of $\mathrm{C}_{25}-\mathrm{C}_{31}$ ) for the core sections $1,3,6$, and 8 are respectively $1.34,1.25,1.37$ and 1.29; these low values indicate fossil fuel contamination. When oil enters the sea, part of it is incorporated with sediment particles and carried down to the sea floor. It is thought that these oil-coated sediments may prevent oxygen from penetration into sediments and thereby protect others lipids from being degraded. In summary, it can be concluded that sedimentary lipid degradation depends more on anoxic environments than on other factors such as the nature of lipids, alternation prior to deposition, etc. 


\section{ACKNOWLEDGEMENTS}

This study was supported by a grant from the National Science Council, Republic of China (grant \# NSC85-2611-M-002A-020-K2).

\section{REFERENCES}

[1] S, M. Henrichs, Early diagenesis of organic matter: The dynamics (rates) of cycling of organic compounds. In Organic Geochemistry: Principles and Applications (Edited by M. H. Engel and S. A. Macko), pp. 101-118. Plenum Press, New York (1991).

[2] J. W. Farrington, N. M. Frew, P. M. Gschwend and B. W. Tripp, Hydrocarbons in cores of northwestern Atlantic coastal and continental margin sediments, Estuar. Coast. Mar. Sci. 5, 793-808 (1977).

[3] V. Santos, D. S. M. Billett, A. L. Rice and G. A. Wolff, Organic matter in deep-sea sediments from the Porcupine Abyssal Plain in the north-east Atlantic Ocean. I--Lipids, Deep-Sea Res. I 41, 787-819 (1996).

[4] P. A. Meyers and B. J. Eadie, Sources, degradation and resynthesis of the organic matter on sinking particles in Lake Michigan, Org. Geochem. 20, 47-56 (1993).

[5] R. I. Haddad, C. S. Martens and J. W. Farrington, Quantifying early diagenesis of fatty acids in a rapidly accumulating coastal marine sediment, Org. Geochem. 19, 205-216 (1992).

[6] M. Y. Sun and S. G. Wakeham, Molecular evidence for degradation and preservation of organic matter in the anoxic Black Sea Basin, Geochim. Cosmochim. Acta 58, 3395-3406 (1994).

[7] E. A. Canuel and C. S. Martens, Reactivity of recently deposited organic matter: Degradation of lipid compounds near the sediment-water interface, Geochim. Casmochim. Acta 60, 1793-1806 (1996).

[8] H. E. Gaudette, W. R. Flignt, L. Toner and D. W. Folger, An inexpensive titration method for the determination of organic carbon in recent sediments, J. Sedi. Perol. 44, 249-253 (1974).

[9] W. L. Jeng and M. P. Chen, Grain size effect on bound lipids in sediments off northeastern Taiwan, Org. Geochem. 23, 301-310 (1995).

[10] M. I. Venkatesan, E. Ruth, S. Steinberg and I. R. Kaplan, Organic geochemistry of sediments from the continental margin off southern New England, U.S.A.--part II, Lipids, Mar. Chem. 21, 267-299 (1987).

[11] R. Pocklington, J. D. Leonard and N. F. Crewe, Sources of organic matter to surficial sediments from the Scotian Shelf and Slope, Canada, Conti. Shelf Res. 11, 1069-1082 (1991). 
[12] W. L. Jeng and B. C. Han, Fatty alcohols and sterols in the continental margin sediments off northeastem Taiwan, Acta Oceanogr. Taiwanica 31, 65-72 (1993).

[13] W. L. Jeng and B. C. Han, Coprostanol in a sediment core from the anoxic Tan-Shui estuary, Taiwan, Estuar. Coast. Shelf Sci. 42, 727-735 (1996).

[14] C. Lee, R. B. Gagosian and J. W. Farrington, Sterol diagenesis in Recent sediments from Buzzards Bay, Massachusetts, Geochim. Cosmochim. Acta 41, 985-992, (1977).

[15] M. Y. Sun, S. G. Wakeham and C. Lee, Rates and mechanisms of fatty acid degradation in oxic and anoxic coastal marine sediments of Long Island Sound, New York, USA, Geochim. Cosmochim. Acta 61, $341-355$ (1997).

[16] C. L. Chen, Sulfate reduction and organic carbon deposition in shelf and slope sediments of the Taiwan Strait, M. S. thesis, National Taiwan University, Taipei, Taiwan, R O. C. (1996).

[17] E. S. Van Vleet and J. G. Quinn, Early diagenesis of fatty acids and isoprenoid alcohols in estuarine and coastal sediments, Geochim. Cosmochim. Acta 43, 289-303 (1979).

[18] S. C. Sun and C. S. Liu, Mud diapirs and submarine channel deposits in offshore Kaohsiung-Hengchun, southwest Taiwan, Perol. Geol. Taiwan 28, 1-14 (1993).

[19] Y. C. Chern, The study of sedimentology, physical and acoustic properties of surface sediments off southwest Taiwan, Ph. D. dissertation, National Taiwan University, Taipei, Taiwan, R. O. C. (1997).

[20] W. L. Jeng, Hydrocarbons in marine sediments off southwestern Taiwan, Proc. Natl. Sci. Counc. ROC 10, 123-129 (1986). 